\title{
PARADIGMA HUKUM ISLAM KLASIK DAN ALTERNATIF
}

\author{
Mohamad Ikrom \\ Fakultas Syariah Institut Agama Islam Inegeri (AIN) Jember | \\ Jhoncenna123@yahoo.com \\ DOI: https://doi.org/10.35719/ijl.v1io1.76
}

\begin{abstract}
Islam is a universal religion, there is no limitation of place and time, therefore Islam should be accepted by every human being on this earth, without having to have "conflict" with the circumstances in which he is. Islamic jurisprudence is a discourse of thought to understand God's terms appropriately, to measure the extent of the freedom of a judge or faqih in determining the law. Muslims are ideologically grouped into four (4) models of social ideological paradigms, among others: Traditionalist Paradigm, Modernity Paradigm, Revival Paradigm; and the Transformation Paradigm. The typology of the Islamic legal paradigm is divided into three (3) major components, namely the Theological Paradigm; Linguistic Paradigm (Language), Methodological Paradigm. These paradigms then describe the characteristics of the study of fiqh which are generally characterized by several characteristics. First, epistemic characteristics, namely, (1) to some extent less separation between time and history, (2) univocalization of meaning, and (3) transhistorical (eternal) reasoning. Other characteristics are, (1) focusing on the study of Islamic law as law in the book, not including law in action, (2) complex branching of material, without paying attention to developing references. (3) polemic, and apologetic, (4) inward looking, and (5) atomistic approach.
\end{abstract}

Keywords: Paradigm Typology, Islamic Law, Fiqh

Abstrak: Islam adalah agama universal, tidak ada keterbatasan akan tempat dan waktu, oleh sebab itu Islam seyogyanya dapat

\section{IJLIL: INDONESIAN JOURNAL OF LAW AND ISLAMIC LAW VOLUME 1 NOMOR 1 JULI-DESEMBER 2019; ISSN 2721-5261}


diterima oleh setiap manusia di muka bumi ini, tanpa harus ada "konflik" dengan keadaan dimana ia berada. Yurisprudensi Islam adalah wacana pemikiran untuk memahami istilah-istilah Tuhan secara tepat, untuk mengukur sejauhmana kebebasan seseorang hakim atau faqih dalam menentukan hukum. Umat Islam secara ideologis dikelompokkan ke dalam empat (4) model paradigma ideologi sosial antara lain : Paradigma Tradisionalis, Paradigma Modernitas, Paradigma Revivalis; dan Paradigma Transformasi. Adapun tipologi paradigma hukum islam dibagi menjadi ke dalam tiga (3) komponen besar, yaitu Paradigma Theologis; Paradigma Linguistik (Kebahasaan), Paradigma Metodologis. Paradigma-paradigma tersebut kemudian menggambarkan karakteristik kajian fiqh yang secara umum ditandai oleh beberapa karakteristik. Pertama karakteristik epistemik, yaitu, (1) sampai batas tertentu kuarang emisahkan antar waktu dan sejarah, (2)univokalisasi makna, dan (3) nalar tranhistoris (abadi). Karakteristik lain adalah, (1) pemujsatan pada studi hukum islam sebagai law in book, tidak mencakup law in action, (2) percabangan materi yang rumit, tanpa memperhatikan referensi yang berkembang. (3) sifat polemik, dan apologetik, (4) inward looking, dan (5) pendekatan atomistik.

Kata Kunci: Tipologi Paradigma, Hukum Islam, Fiqih

\section{Pendahuluan}

Al-Qur'ân menyatakan bahwa lingkup keberlakuan ajaran Islam yang dibawa oleh Nabi Muhammad saw adalah untuk seluruh umat manusia, dimana pun mereka berada. ${ }^{1}$ Oleh sebab itu, Islam seyogyanya dapat diterima oleh setiap manusia di muka bumi ini, tanpa harus ada "konflik" dengan keadaan dimana ia berada, secara implisit, Islam akan berhadapan dengan masyarakat modern dan ia dituntut

\footnotetext{
${ }^{1}$ QS (Saba): 28 dan Al-Anbiya: 107
} 
untuk dapat menghadapinya. Berdasarkan fenomena tersebut, maka posisi serta peranan ijtihad sangat penting dalam pengistinbatan hukum syara' dan kita juga harus menghargai dan memahami berbagai macam tipologi mazhab yang lahir dalam Islam. ${ }^{2}$

Yurisprudensi Islam adalah sebuah wacana pemikiran untuk memahami istilah-istilah Tuhan secara tepat. ${ }^{3}$ Sehingga sejauhmana ukuran kebebasan seseorang hakim atau faqih dalam menentukan hukum terhadap proses umum dari usaha yuridis untuk mengetahui dengan pasti istilah-istilah hukum Tuhan melalui ijtihad.

Jadi, doktrin para fuqaha pada awalnya muncul dengan otoritas yang mereka sendiri tidak pernah mengklaim untuk itu. Karya-karya tulis mereka menjadi bahan yurisprudensi "buku induk" mazhab dan menjadi subyek penjelasan yang mendalam yang makin berkembang oleh generasi muridmurid berikutnya yang tetap setia memelihara substansi dasar ajaran gurunya. Sehingga secara formal yurisprudensi mengakui bahwa kemampuan kreatif telah lenyap, berarti pintu ijtihad 'telah tertutup'. Generasi ahli hukum masa berikutnya tidak lagi mempunyai hak penyelidikan yang independent dan bahkan diikat oleh prinsip taqlid kepada

\footnotetext{
${ }^{2}$ Weal B.Hallaq, Authority Continuity and Change in Islamic Law, (New York, Cambridge University Press,2001), hal. 1-8.

3 Noel J. Coulson, Konflik Dalam Yurisprudensi Islam, pengantar Akh.minhaji, (Yogyakarta, Navila), hal. 49-52.
} 
doktrin para pendahulunya. Pada tataran selanjutnya fiqh memiliki pengaruh dalam kehidupan sehari-hari dimana fiqh sebagai paradigma keadilan harus dikaitkan dengan peta ideologi dan teologi umat Islam dalam meresponi formasi sosial, baik pada tingkat nasional maupun pada tingkat global.

\section{Pembahasan}

\section{Paradigama Ideologi Sosial Umat Islam}

Umat Islam secara ideologis, dewasa ini dapat dikelompokkan ke dalam empat (4) model paradigma ideologi sosial antara lain ${ }^{4}$ :

a. Paradigma Tradisionalis ; menurut kaum tradisionalis bahwa masalah kemiskinan yang diderita umat Islam adalah taqdir yang hanya Tuhan yang mengetahui rahasia dibalik keputusan tersebut. Dalam agama Islam akar teologi agama ini adalah konsep sunni tentang taqdir, khususnya ajaran asy-'Ariyah. Bagi manusia memiliki "free will" untuk menciptakan nasib mereka meskipun mereka berusaha secara maksimal akhirnya Tuhan jugalah yang memutuskan.

b. Paradigma Modernitas. Perspektif kaum modernis ini pada dasarnya memiliki kesamaan dengan kaum modernis di dunia sekuler yang percaya bahwa akar

\footnotetext{
4 Noer Akhmad, dkk, Epistimologi Syara'-Mencari Format Baru Fiqh Indonesia, (Yogyakarta: Pustaka Pelajar, 200o), hal. 133-143.
} 
masalah bagi kaum muslim karena ada "something wrong”, dengan teologi dan mentalitas. Isu utama mereka adalah perang melawan bid'ah dan khurafat, mereka dikenal sebagai gerakan "furifikasi" dan "reformasi" sehingga Islam mengalami kemunduran dalam aspek kehidupan disebabkan umat Islam tidak berpartisipasi dalam pembangunan.

c. Paradigma Revivalis; Kaum revivalis melihat faktor internal dan eksternal sebagai ancaman bagi umat. Seperti mencari ideologi lain atau isme lain sebagai referensi ketimbang menggunakan Al-Qur'ân sebagai referensi prinsip dasar. Mereka juga melihat afama dan ideologi kain sebagai ancaman utama Islam, termasuk marxisme, kapitalisme, Kristen dan ideologi barat.

d. Paradigma Transformasi, menurut paham ini bahwa kemiskinan adalah disebabkan oleh ketidakadilan sistem dan struktur ekonomi, politik, dan budaya. Tujuan utama mereka adalah mentransformasikan struktur yang ada, dengan menciptakan tatanan yang lebih baik dalam aspek ekonomis, politik, dan kultur, yakni suatu proses penghapusan ketidakadilan dalam eksploitasi ekonomi, pendindasan politik, hegemoni kultural serta penghormatan atas hak-hak azasi manusia. Keadilan menjadi sebuah prinsip dasar 
paradigma ini. Fokus mereka dalam membangun akar teologi, metodologi, pendekatan dan aksi untuk mentranformasikan masyarakat dimana pada dasarnya adalah paham keadilan dalam Islam.

\section{Tipologi Paradigma Hukum Islam}

Paradigma diartikan sebagai seperangkat keyakinan dasar yang membentuk suatu sistem pemikiran yang memberikan kepada kita suatu penilaian mengenai hakikat realitas atau alasan mengapa kita menerima pengetahuan mengenai suatu yang kurang dari realitas sebenarnya beserta metode untuk menguasai apa saja yang dapat diketahui. ${ }^{5}$

Sebagaimana telah dipahami, bahwa paradigma hukum Islam dapat dibagi ke dalam tiga (3) komponen besar, sebagai berikut:

a. Paradigma Theologis; menekankan bahwa dasar pokok hukum Islam adalah terdapat pada keyakinan theologies, sehingga muncul term teologi seperti :

1) Paham Tradisionalis

Teologi Asy-'Ariyah memberikan tekanan kepada kuasa dan kehendak mutlaq Tuhan. Segala sesuatu tergantung pada kekuasaan dan kehendak-Nya yang bersifat mutlaq. Karenanya, menurut mereka tidak ada hubungan kausal yang

\footnotetext{
${ }^{5}$ Lincoln dan Guba, Naturalistic inquiry, (Baverly Hill, California: Sage Publications, inc, 1985), hal. 15.
} 
efektif di dalam alam, sebab hal itu akan berarti membatasi kemutlakan kuasa kehendak Tuhan. ${ }^{6}$

Bahkan salah seorang tokoh pandangan ini yang karya teologisnya menjadi pemandu teologi umat Islam selama berabad-abad, menyatakan bahwa percaya kepada hukum sebab akibat itu adalah salah satu dari enam pokok-pokok kekafiran. Enam pokok sebab kekafiran itu adalah, pertama, percaya kepada prinsip kepercayaan, kedua, baik buruk itu adlah suatu yang rasional, ketiga, ta'lid buta, keempat, adanya hubungan kausalitas, kelima, jahil murokkab (bodoh sekali), keenam, berpegangan pada zhahir teks mengenai dasar-dasar aqidah. Asy-Syatibi $\left(\begin{array}{lll}750 & \mathrm{H}\end{array}\right)^{7}$ merumuskan masalah ini dalam kata-katanya "sebab, tidak memberi efek dengan sendirinya (untuk terjadinya akibat), akibat terjadi bersamaan dengan dan bukan karena sebab ......" akibat adalah perbuatan Tuhan yang maha tinggi, jadi menurut asy-Syatibi tidak ada hubungan kausalitas antara sebab dan akibat yang terjadi bersamaan, akan tetapi akibat bukan efek dari sebab.

Akibat adalah dari kehendak Tuhan yang

\footnotetext{
${ }^{6}$ Amir Mu'alim dan Yusdani, Konfigurasi Pemikiran Hukum Islam, Pengantar M.Mahfud MD, (Yogyakarta: UII Press,2001), hal.21-22.

${ }^{7}$ Asy-Syatibi, Al-Muwafaqat fi Ushul al-Ahkam, (http, Dar al-Fikr,134 H).
} 
dapat melakukan apa saja yang dikehendaki. Dalam kaitannya dengan manusia, pandangan yang menekankan kuasa dan kehendak mutlaq Tuhan berakibat ditempatkannya makhluk ini pada posisi lemah. Kompetensi akalnya hanya diakui secara amat minimal sehingga ia tidak mampu dengan akalnya itu untuk mengetahui baik dan buruknya suatu perbuatan yang menjadi obyek hukum. Lagi pula pada perbuatan itu tidak terdapat suatu kualitas instrinsik yang menyebabkannya menjadi baik dan buruknya suatu perbuatan yang dapat dipatoki oleh akal.

Untuk mengetahui baik dan buruknya suatu perbuatan itu, akal tidak mengetahuinya. Baik dan buruk semata-mata karena perintah atau larangan Tuhan. Alasan Asy-'Ariyah adalah; seandainya baik-buruk itu bersifat rasional dan dapat diketahui oleh akal, hal itu akan berakibat terjadi perbedaan-perbedaan dalam menilai baik dan buruknya perbuatan-perbuatan, sebab akal itu berbeda tigkat kemampuannya menilai perbuatan. Apa yang dipikirkan sebagai fisik oleh sebagian orang bisa jadi dipandang sebaliknya oleh orang lain.

2) Paham Rasionalis 
Paham ini diwakili oleh kelompok syi'ah dan Mu'tazilah. Mu'tazilah yang didirikan oleh wasil bin ata' (w.130/748), yang mengajarkan lima prinsip dasar yaitu : keesaan Tuhan, janji dan ancaman, posisi antara dua posisi, dan amar ma'ruf Nahi mungkar. Wacana yang dibahas oleh kelompok ini, terkait dengan "keadilan Tuhan" yang intinya menyatakan bahwa 'manusia sebagai makhluk yang berakal, mampu melahirkan hukum. Hukum Islam telah dilukiskan sebagai hukum Tuhan sekaligus hukum yang dilahirkan oleh para fuqaha. ${ }^{8}$

Manusia adalah satu-satunya makhluk yang mempunyai kebebasan untuk memilih sendiri jalan kehidupannya dan kemampuannya untuk mengembangkan dirinya. ${ }^{9}$ Roh adalah salah satu unsur yang terdapat pada menusia, daya roh yang mampu membuat konsep atau berfikir disebut akal. Akal merupakan salah satu dari daya roh yang memungkinkan manusia untuk mengetahui sunnah-sunnah Allah dan memanfaatkannya untuk keperluan hidup, sehingga manusia tidak menyerah begitu saja kepada alam, manusia

\footnotetext{
${ }^{8}$ Konflik Dalam Yurisprudensi,...., hal. 4.

${ }^{9}$ Machasin, Menyelami Kebebasan Manusia-Telaah Kritis Terhadap Konsepsi Al-Qur'an, (Yogyakarta,INIS, 1996), hal. 119-129.
} 
mengubah alam dengan memahami hukumhukum Allah yang berlaku pada alam itu untuk kepentingannya sendiri. Paradoks yang ada pada diri manusia, kebebasan dan keterikatan ini, dalam kenyataan sejarah telah melahirkan dua aliran ekstrem tentang perbuatan manusia dalam hubungannya dengan perbuatan Allah.

Paham Jabariyah berpendapat bahwa manusia tidak mempunyai kemampuan sama sekali untuk menentukan perbuatan, karena pada dasarnya Allah telah menentukan perbuatanperbuatan sejak azali dan mewujudkannya pada manusia atas kemampuannya sendiri. Faham Qadariyah justru sebaliknya, bahwa manusia mempunyai kebebasan dan kekuatan sendiri untuk mewujudkan perbuatannya, Allah sama sekali tidak menentukan sebelumnya.

Konsekuensi lebih lanjut dari prinsip keadilan Ilahi, menurut Mu'tazilah adalah bahwa manusia menciptakan perbuatannya. Penjelasan pandangan ini adalah untuk menjelaskan arti tanggungjawab manusia. Adalah tidak adil dalam pandangan paham ini, apabila manusia tidak menciptakan perbuatannya akibatnya lebih jauh dari pemberian tanggungjawab yang besar kepada 
manusia dan sebagai manifestasi dan kebebasaannya adalah bahwa orang-orang Mu'tazilah memberikan penghargaan yang tinggi kepada kemampuan akal, diakui melalui akal dapat mengetahui baik dan buruk. Wahyu dalam hal ini memberikan konfirmasi terhadap penemuan akal. Menurut pandangan Mu'tazilah, apabila diketahui suatu perbuatan mengandung kemudaratan dan bahaya, hukumnya haram, dan mengerjakan perbuatan tersebut hukumnya wajib apabila suatu perbuatan mengandung maslahat. Dari uraian diatas bahwa akal dapat mengetahui hukum Syar'i dalam sebagian besar berdasarkan kualitas etis yang ada pada perbuatan tersebut.

3) Paham Moderat

Ulama-ulama Maturidiah (yang dalam fiqh menganut mazhab Hanafi), terutama Maturidiah muta'akhirin, mencoba mengambil jalan tengah, Mereka berpendapat bahwa akal dapat mengetahui baik dan buruknya suatu perbuatan. Akan tetapi, dengan mengetahui baik-buruknya suatu perbuatan itu tidak dengan sendirinya akan mengetahui hukum Allah tentang perbuatan tersebut dan baginya Tuhan adalah pemberi hukum, Syara' pemberi informasi tentang hukum 
dan akal hanya bisa mengetahui yang baik dan buruk.

Pertumbuhan dan perkembangan teologi dogmatik dalam Islam diindikasikan oleh ${ }^{10}$ antara lain:

a) Nabi-nabi bukanlah Teolog; para teolog (ulama) itulah yang menjawab soal-soal yang berada diluar lingkup perhatian Nabi. Mereka inilah yang merasa terpanggil untuk menafsirkan wahtuwahyu Nubuat.

b) Karena suasana politik di satu pihak, dan dorongan-dorongan kontak dengan dunia luar di lain pihak. Melibatkan kaum muslim awal yang belum banyak tertarik untuk mengungkapkan pernik-pernik teologis, merasa perlu untuk mengambil posisi yang tegas terhadap masalahmasalah yang oleh Al-Qur'ân tidak diberi jawaban, seperti; revolusi Ummayyah yang telah memberikan kepada kaum muslim situasi politik dan ketatanegaraan yang baru.

c) Munculnya term tentang siapa yang dikatakan sebagai 'seorang muslim sejati, dalam hal ini wacana yang diusung adalah tentang kekuasaan dan kebenaran Allah.

${ }^{10}$ Ignaz Goldziher, Introduction To Islamic Theology And Law, terj. Pengantar Teologi Thm Hukum Islam, (Jakarta: INIS, 1991 ), hal. 65-112. 
d) Bahwa Al-Qur'ân bisa digunakan untuk memberikan bukti kebenaran terhadap pandangan-pandangan yang paling berlawanan terkait dengan etika keagamaan, terkait dengan masalah taqdir'.

e) Munculnya filsafat Aristotelis, dimana banyak para pelajar muslim terpengaruh oleh flisafat tersebut dalam pemikiran keagamaan mereka, sehingga muncul ilmu kalam dalam Islam, dan lain-lain.

b. Paradigma Linguistik(Kebahasaan)

Paradigma Linguistik merupakan pandangan tertentu mengenai bahasa dan cara bekerjanya yang mempengaruhi proses penalaran hukum Islam dan produknya. Interpretasi Linguistik merupakan peruwujudan penemuan Hukum Islam dengan cara melakukan interpretasi terhadap teks-teks hukum Islam yang ada, yaitu nash-nash Al-Qur'ân dan Hadits. Dalam hal ini, suatu kasus yang dihadapi sudah ada teks hukumnya, hanya saja nash atau teks hukum tersebut masih kabur atau kurang jelas.

Penyelidikan terhadap berbagai pernyataan hukum dalam metode ini merupakan menghasilkan taksonomi yang mengklasifikasikan pernyataan hukum dalam teks-teks hukum itu dan empat (4) 
segi ${ }^{11}$ :

1) Dari segi tingkat kejelasan pernyataan; dapat dibedakan pernyataan hukum yang jelas meliputi: ظاهر (zahir), nass (نصا), mufassar (مفر), muhkam (محكم) . Dan pernyataan Hukum yang tidak jelas meliputi: khafi, musykil, mujmal, dan mutasyabih.

2) Dari segi bentuk-bentuk penunjukan terhadap makna (Hukum), yang terbagi dalam ; penunjukan secara langsung (Dalalah al-Ibarah), penunjukan secara implisit (Dalalah al-Isyarah), penunjukan secara analog (Dalalah Al-Dalalah), penunjukan secara sisipan ( Dalalah Al-Iqtida).

3) Dari segi luas-sempitnya cakupan makna dalam suatu pernyataan hukum, meliputi pernyataan : umum, khusus, pernyataan bermakna ganda, hakiki, majazi, dan lain-lain.

4) Dari segi bentuk-bentuk formulasi Taklif, seperti kategori perintah dan larangan.

Dalam pendahuluan Al-Mustasfa ${ }^{12}$ Al-Ghazali mensyaratkan logika. Siapapun yang tidak mempunyai logika, maka ilmu pengetahuannya tidak valid. Sebenarnya, ilmu ushul fiqh mempunyai logika khusus

\footnotetext{
${ }^{11}$ Anwar, Metodologi Hukum Islam,.... hal. 15.

${ }^{12}$ A1-Ghazali, Al-Mustasfa min ilm Ushul, (Bairut/Libanon: Al-Risalah, 1994 M ), hal. 913.
} 
yang lebih universal dan komprehensif daripada logika formal. Penyataan ini direlasikan pada penegasan bahwa logika adalah alat (sarana) bagi totalitas ilmu pengetahuan, bukan hanya bagi ilmu ushul fiqh. Tidak dapat dipungkiri, bahwa terjadi kontroversi antara proporsi-proporsi dengan logika dan bahasa, sehingga muncul aliran-aliran, seperti:

a) Aliran Optimistik; mereka berpendapat optimis, bahwa bahasa sudah cukup untuk membaca teksmelahirkan hukum, tidak perlu lagi sarana atau alat lain. Pandangan Optimistik ini didasarkan kepada beberapa asumsi dasar mengenai bahasa, pertama : bahasa dianggap merupakan sarana yang cukup untuk komunikasi, kedua : membaca suatu teks sudah cukup untuk memperoleh pengetahuan mengenai realitas tanpa memerlukan alat lain, ketiga : bahwa bahasa itu merupakan sunnah yang baku dan konstan serta merupakan endapan data linguistik yang tidak berevolusi. ${ }^{13}$ Oleh sebab itu, suatu ungkapan harus diartikan menurut makna yang telah ditetapkan untuknya dan tidak dapat diartikan lain kecuali ditemukan bukti yang tegas

\footnotetext{
${ }^{13}$ Di kutip dari makalah Prof. Syamsul Anwar "Paradigma Fiqh Kontempore-mencari arah baru telaah Hukum Islam", atau lihat... Bernard G.Weiss The Search For God's Law Islamic Jurisprudence In The Writings Of Saif al- Din al-Amidi (Salt Lake city: University of Utah Press, 1992), hal. 124.
} 
bahwa arti lain itu memang dimaksudkan. Dengan kata lain suatu bentuk linguistik tertentu harus diartikan menurut arti zahirnya dan tidak dapat disimpangi tanpa justifikasi yang cukup.

b) Aliran Skeptis; mereka berpendapat bahwa bahasa tidak cukup untuk menemukan hukum, tapi juga sangat memerlukan sarana atau alat lain, seperti kajian sosiologis yang melingkupi keadaan dan waktu tertentu, yang dapat direlasikan dengan adanya model ijtihad, atau qiyas dalam hukum Islam. Bahasa adalah milik publik, sehingga maknanya bersifat obyektif karena ia terbilang ke dalam ranah publik. Seperti yang dikutip oleh Prof. Syamsul Anwar ${ }^{14}$ dari Syabrastani (W. 548 H/1153 M) yang berbunyi “ tidak semua kasus ditemukan ketentuan hukumnya dalam tek-teks, teks-teks hukum itu terbatas adanya.....sementara kasus-kasus hukum tidak terbatas”... (an-nusus mutanahiah wa al waqa'i gair mutanahiah) oleh sebab itu sangat diperlukan adanya ijtihad di kalangan umat Islam.

Oleh karena itu, nilai-nilai atau aturan hukum (Ahkam Asy-Syar 'Iyyah), hadir pada posisi pertama,

${ }^{14}$ Syamsul Anwar, "Teori Konformitas dalam metode penemuan Hukum Islam al-Ghazali (tt:tp). 
dasar-dasar aturan hukum (Al-Adillah Syar 'Iyyah) pada posisi kedua, kemudian. cara-cara atau metode analogi pada posisi ke tiga, posisi terakhir adalah ketentuan-ketentuan ijtihad, taqlid, dialektika kontradiktif dan tarjih. ${ }^{15}$ Oleh sebab itu wahyu harus dihadirkan pada permulaan, sedangkan cara-cara analogi secara natural adalah di tengah-tengah. Ushul fiqh merupakan metode yang mendiskripsikan tindakan-tindakan dan tujuan-tujuan mukallaf, sebagaimana wahyu mendiskripsikan sendiri yang disebut "tendensi", maka ushul fiqh itu menuntut tiga (3) klasifikasi yang berangkat dari kesadaran dikalangan kita, yaitu:

a) Kesadaran Historis (asy-syu'urat tarikhi), yang berfungsi menjamin validitas teks-teks wahyu dalam sejarah.

b) Kesadaran Eidetis (asy-syu'urat at-ta'ammuli); yang berfungsi untuk memahami teks-teks wahyu dan interpretasinya yang dimulai dengan maksimmaksim bahasa dan asbab an-nuzul (argumentargumen pemahaman wahyu).

c) Kesadaran praksis (asy-syu'urat al-amali); yang berfungsi merelevansikan nilai-nilai aturan hukum

${ }^{15}$ Harun Nasution, Dasar Pemikiran Pembaharuan Dalam Islam, Jakarta: Pustaka Panji Mas, 1985), hal. 13-14. 
dalam kehidupan dunia dan memanifestasikan tendensi-tendensi wahyu dalam sejarah.

c. Paradigma Metodologis

Paradigma Metodologis/epistimologis merupakan pandangan tertentu yang memuat asumsi metodologis. Bagi para ahli hukum Islam zaman lampau, penyelidikan tentang hukum didasarkan atas Tab`iyyah al-aql li an-naql (bahwa naql didahulukan atas aql', sehingga naqallah yang diikuti oleh akal).. Dengan kata lain akal tidak dibebaskan dalam melakukan penyelidikan kecuali sejauh yang dibenarkan oleh naqal. ${ }^{16}$

Ini berarti bahwa analisis Hukum Islam adalah Naqli atau analisis teks, sesuai dengan anggapan bahwa tidak ada Hukum di luar teks-teks naqliah, dan bahwa bahasa dan teks telah merupakan sarana yang mencukupi. Oleh sebab itu, ilmu Hukum lslam di masa lalu boleh dikatakan sebagai ilmu teks atau "Ilmu Kalam" dengan kata lain ilmu yang menyelidiki kalam Ilahi untuk daripadanya ditemukan Hukum fiqh, ulama masa lalu tidak pernah mengembangkan suatu metode analisis sosial dan historis yang tanpa ada upaya menggandengkan berbagai konsep di dalamnya dengan konsep-konsep paralel dalam sistem

\footnotetext{
${ }^{16}$ Asy-Syatibi,...., hal. 1:53.
} 
Hukum lain melalui metode komparatif yang obyektif.

Selain itu juga pendekatan klasik dalam kajian fiqh masih bersifat Atomistik. Memang para ilmuan muslim pada masa lampau telah mengembangkan ilmu-ilmu kealaman dan ilmu pasti yang didasarkan pada pendekatan emperis dan induktif (pendekatan burhani), namun untuk ilmu-ilmu sosial seperti; politik, sosiologi (kecuali Ibn Khaldun), psikologi, pendekatan emperis dan induktif absen dari kegiatan keilmuan disebabkan tidak adanya induksi dan investigasi sistematik dan emperis mengenai manusia dan realitas sosial dalam masyarakat. ${ }^{17}$

Para ulama masa lalu menganggap deduksi dan teks-teks agama merupakan sarana utama guna memperoleh pengetahuan mengenai prinsip-prinsip dan partikular sistem sosial menurut syari'ah. ${ }^{18}$ Memang dilematis, karena sampai saat inipun, masih ada sebagian ilmuan Islam yang mengabaikan interpretasi teks dengan mengabaikan realitas emperis masyarakat.

Adanya perbedaan paradigma para ilmuan Islam dalam memandang serta menempatkan kedudukan

\footnotetext{
${ }^{17}$ Anwar, Metodologi Hukum Islam,...., hal. 4.

${ }^{18}$ Abdul Hamid Abu Sulayman, Towards An Islamic Theory Of Interational Relations ; New Direction For Methodology And Thought, (Herndon, VA: International Institute of Islamic Thought, 1994), hal. 87.
} 
teks-teks Al-Qur'an dan Hadits sabagai sumber hukum Islam, maka secara implisit akan sangat mempengaruhi kajian polarisasi metodologi mereka dalam pengistinbatan hukum Islam, seperti model metode yang ditawarkan oleh Louay Safi (komparasi analisis tekstual dan analisis sosial terkait dengan teori sistem prilaku) dan Az-Zarqa' (adanya integrasi antara Naql dan aql aspek bidang ekonomi Islam). ${ }^{19}$

Sebagaimana dikaji dalam ushul fiqh, sarana untuk mengadakan perubahan dan pembaharuan hukum dalam Islam adalah "ijtihad", yang menurut Iqbal $^{20}$ ijtihad merupakan "the principle of movement', daya gerak kemajuan umat Islam. ${ }^{21}$ dimana munculnya dikarenakan adanya persentuhan antara ajaran Islam di satu pihak dan tuntutan realitas kehidupan manusia di lain pihak. Teori ijtihad dalam hukum Islam menimbulkan dan merupakan kunci dinamika ajaran Islam, termasuk bidang hukumnya. Permulaan epistimologi hukum Islam karena menyangkut peran "wahyu dan akal".

Sekalipun peran wahyu dan akal semula merupakan pokok bahasan dalam ilmu Kalam

\footnotetext{
19. Anwar, Metodologi Hukum Islam,.,..., hal. 5- 12.

${ }^{20}$ M.Iqbal. The Reconstruction Of Religius Thought In Islam, (India: Kitab Bhavana, 1981), hal.147-148.

${ }^{21}$ Fathurrahman Djamil, Metode Ijtihad Majlis Tarjih Muhammadiyah, (Jakarta: Logos Publishing House, 1995), hal. 12.
} 
(teologi), tetapi dalam perkembangannya permasalahan proses wahyu dan akal telah masuk dan mempengaruhi pandangan para ahli hukum Islam, karena teologi merupakan persoalan ushul (pokok) dan fiqh adalah furu'nya (cabang), yang berarti ilmu kalam menjadi landasan fiqh. Dengan kata lain, pandangan-pandangan ahli hukum Islam sangat dipengaruhi oleh corak 'teologi' yang dianutnya, baik teologi rasional, irrasional, atau moderat. ${ }^{22}$

Untuk itulah studi fiqh sebagai Hukum perlu dilakukan dengan pendekatan asas-asas dan filosofis yang akhir-akhir ini mulai dilakukan dengan lahirnya apa yang disebut dengan An-Nazariyyat Al- Fiqhiyyah, untuk itu ${ }^{23}$ norma-norma Hukum Islam dapat ditata dalam tiga (3) tingkat, yaitu : (1) Nilai-nilai dasar (Qiyam al-Asasiyyah), (2) asas-asas umum/doktrindoktrin umum (al-Usul al-Kuliyyah), (3) peraturan hukum konkrit sehingga hal tersebut menunjukkan bahwa perubahan dan pembaharuan hukum Islam pada masa kini dan masa yang akan datang haruslah pula menyentuh aspek teologis yang melandasi pemikiran-pemikiran ushul fiqh, terutama mencari bagaimana dan apa sumber diperolehnya pengetahuan

\footnotetext{
${ }^{22}$ Amir Mu'alim \& Yusdian, Konsfigurasi Pemikiran Hukum Islam, (Yogyakarta: UII Press, 2001), hal. 3.

${ }^{23}$ Anwar, Metodologi Hukum Islam.
} 
hukum dalam Islam, apakah akal di samping wahyu dapat mengetahui dan menentukan perbuatan baik buruk, baik sebelum ataupun sesudah turunnya wahyu meniscayakan adanya kewajiban syara' atau tidak?, di samping itu, aspek epistimologis hukum Islam lainnya yang sudah saatnya di kembangkan oleh para pakar hukum Islam, guna mengembangkan hukum Islam di samping menempatkan fiqh sebagai hasil ilmu, yang memposisikannya sebagai ilmu.

Gambaran tentang kemampuan syari'at Islam dalam menjawab persoalan modern dapat diketahui dengan menemukan beberapa prinsip syari'at Islam, mengenai tatanan hidup secara vertikal dan horizontal.

Kebanyakan ahli fiqh telah menetapkan kaidah bahwa hukum asal segala sesuatu dalam bidang material dan hubungan antar sesama manusia (mu'amalat) adalah boleh, kecuali apabila ada dalil yang menunjukkan bahwa sesuatu itu terlarang. ${ }^{24}$ AsySyatibi ${ }^{25}$, mencoba membedakan materi hukum Islam yang menyangkut ibadah dan yang kedua materi hukum Islam yang menyangkut Mu'amalat (adat): Alashlu fi al-ibadah binnisbati ila al-mukallaf at-ta'abbud

\footnotetext{
${ }^{24}$ Fathurrahman Djamil, Filsafal Hukum Islam, (Jakarta: Logos Wacana timur, 1999), hal. 40 .

${ }^{25}$ As-Syatibi, Al-Muwafaqat Fi Ushul Al-Ahkam juz 2, (Bairut: dar Fikr, 1341 H), hal. 211.
} 
duna al-iltifatila al-ma'any wa ashlu al-'adah al-iltifat ila al-ma'any (prinsip dalam persoalan ibadah bagi mukallaf adalah ta'abbud tanpa perlu melihat kepada nilai atau hikmah, sedangkan prinsip-prinsip dalam persoalan adat (mu'amalat) adalah melihat kepada nilai atau hikmah)

Sebagaimana telah dipahami, bahwa sumber primer dan pemahaman dalam Islam adalah "wahyu Tuhan”. Dalam kepercayaan Islam ortodoks, hal ini dibatasi secara ketat sebagai wahyu yang diberikan Tuhan kepada pilihan-Nya Nabi saw. Wahyu itu nampak dalam bentuk pertama: dalam teks Al-Qur'ân yakni firman Allah sendiri, kedua; dalam bentuk aktifitas dan keputusan Nabi sebagai pemimpin masyarakat Islam, namun Al-Qur'ân dan sunnah secara bersama-sama tidak meliputi pengertian yang merupakan kitab undang-undang yang komprehensif. Materi hukum yang dikandungnya adalah sebuah koleksi dan putusan-putusan yang berangsur-angsur terhadap persoalan-persoalan khusus yang tersebar luas dalam berbagai topik yang berbeda.

Norma hukum, yang ditetapkan Al-qur'an dan sunnah pada dasarnya merupakan modifikasi Ad Hoc dan hukum adat yang berlaku masih merupakan norma tingkah laku yang diterima, kecuali kalau digantikan 
secara khusus oleh keadaan baru yang menimbulkan persoalan baru, hal ini diserahkan kepada ahli hukum (faqih) berdasarkan pertimbangan yang dipandang sesuai. Dalam proses mengungkapkan pendapatnya yang dikenal "ra'yu", setiap orang bebas memperhitungkan faktor-faktor yang dianggap relevan.

Secara singkat pada awalnya, hukum Islam mempunyai dasar rangkap yang berbeda. Dasar tersebut merupakan gabungan dari dua ruang lingkup yang terpisah yaitu wahyu Tuhan dan keputusan manusia. Tetapi sikap pragmatis ini segera menjadi persoalan, setelah munculnya upaya sistematisasi pemikiran teologi dan filsafat pada zaman klasik seperti munculnya kelompok:

a) Ahlul-Hadits

Menurut mereka bahwa setiap aspek tingkah laku manusia harus di atur oleh kehendak Tuhan dan kedaulatan hukum Tuhan mencakup segalanya. Memberi peluang pada pemikiran manusia untuk merumuskan suatu aturan hukum, apakah dengan penerimaan secara terus-menerus hukum adat atau melalui pemikiran yang bersifat spekulatif merupakan penolakan terhadap aturan Tuhan, dalam bahasa teologi Islam adalah 
“mengadakan saingan bagi Allah", dan menyangkal doktrin dasar tentang keMahatahuan dan keMahakuasaan sang pencipta (Allah). Pada dasarnya kelompok ini, percaya bahwa setiap norma hukum harus berasal dari Al-Qur'ân atau praktek Nabi yang dikenal dengan "Hadits".

b) Ahlul Ra'yu

Paham mereka ini, sangat kontradiktif dengan paham ahlul Hadits. Kelompok ini berpandangan bahwa penggunaan akal bebas untuk menguraikan hukum adalah sah dan perlu. Asy-Syafi'i sebagai pendiri ushul fiqh mengakui perlunya akal manusia untuk menetapkan aturan hukum terhadap situasi yang secara nyata atau secara khusus tidak diatur oleh wahyu Tuhan. Tetapi akal di sini tidak digolongkan ra'yu atau sebagai sumber hukum yang terlepas dari kehendak Tuhan dalam mencapai tujuan yang diinginkan para ahli hukum. Oleh karena itu, peran manusia harus sepenuhnya di tempatkan dibawah prinsip-prinsip yang telah ditetapkan oleh wahyu Tuhan. Fungsi akal adalah mengatur kasus-kasus yang baru dengan cara memberlakukan kasus baru tersebut di atas prinsip wahyu. 
Teologi ${ }^{26}$ sebagai ilmu yang membahas soal keTuhanan dan kewajiban-kewajiban manusia terhadap Tuhan, memakai akal dan wahyu dalam memperoleh pengetahuan tersebut tentang kedua soal tersebut. Akal sebagai daya berfikir yang ada dalam diri manusia, berusaha keras untuk sampai kepada diri Tuhan, dan wahyu sebagai pengkhabaran dari alam metafisika turun kepada manusia dengan kategori-kategori tentang Tuhan dan kewajiban-kewajiban manusia terhadap Tuhan.

Mereka tidak puas hanya dengan pernyataan superioritas akal atas tradisi, tetapi lebih jauh lagi menyamakan derajatnya dengan firman Tuhan sebagai petunjuk agama. Akan tetapi, tidaklah dapat disangkal bahwa gerakan Mu'tazillah memberikan konstribusi internal yang besar kepada Islam, tidak hanya dengan mencoba menegakkan gambaran Tuhan sebagai pembangunan moral bagi pikiran yang maju, tetapi di atas segalanya juga atas desakan mereka mengenai klaim akal dalam theology. Kaum Mu'tazilah teguh pada akal dan keadilan Tuhan

${ }^{26}$ Harun Nasution, Teologi Islam-Aliran-Aliran Sejarah Analisis Perbandingan, (Jakarta: Universitas Indonesian Press, 1986), hal.79. 
serta kemerdekaan berkehendak manusia.

Bagi Mu'tazillah, prinsip “Keadilan Tuhan”, mengajarkan bahwa Tuhan Maha bijaksana, tidak akan bertindak secara semena-mena, tetapi dalam tindakan-Nya itu terkandung kebijaksanaan dan tujuan. Oleh karena itu, pastilah Tuhan berbuat untuk kepentingan orang lain, yang dalam hal ini adalah mahluknya. Jadi, kemaslahatan dan kebaikan mahluk tujuan yang terkandung dalam perbuatan Tuhan.

Demi keadilan-Nya Allah tidak akan berbuat zalim dan buruk terhadap mahluknya. Konsekwensi lebih lanjut dan prinsip keadilan ilahi, menurut Mu'tazillah adalah bahwa manusia menciptakan perbuatannya. Akibat yang jauh dari pemberian tanggung jawab yang besar kepada manusia dan sebagai manifestasi dari kebebasannya adalah bahwa orang-oing Mu'tazillah memberikan penghargaan yang tinggi kepada kemampuan manusia yang di akui dapat melalui akalnya, mengetahui yang baik dan buruk. Wahyu dalam hal ini memberikan konfirmasi terhadap penemuan akal.

Terkait dengan metodologi (komparasi analisis tekstual dengan analisis sosial) yang banyak ditawarkan pada saat ini, 
merupakan salah satu bukti adanya kedinamikaan perkembangan pemikiran intelektual muslim dalam rangka merespon problema kontemporer umat. Menurut Penulis bahwa akal mempunyai potensi dan kapasitas untuk menggali serta menemukan hukum baru baik yang sudah ter-redaksi dalam teks-teks Al-Qur'an maupun Hadits. Potensi akal yang dimaksudkan penulis adalah bukanlah akal dalam arti yang seluas-luasnya, akan tetapi penggunaan akal akan dibenarkan jika masih berada dalam koridor Hukum Tuhan serta tetap memperhatikan kemaslahatan dan menjauhi kemafsadatan umat.

Rasionalisasinya Menurut kaum Mu'tazilah bahwa segala pengetahuan dapat diperoleh dengan perantaraan akal, dan kewajiban-kewajiban dapat diketahui dengan pemikiran yang mendalam. Wahyu mempunyai fungsi sebagai pemberi penjelasan tentang perincian hukuman dan imbalan yang akan diterima manusia di akhirat Sedangkan kaum Asy'Ariyah, menolak sebagian postulat kaum Mu'tazilah. Menurut mereka bahwa akal tersebut dapat membuat sesuatu menjadi wajib dan tidak dapat mengetahui bahwa mengerjakan yang baik dan menjauhi yang buruk adalah kewajiban wajib bagi manusia. Betul, akal dapat mengetahui Tuhan, tapi wahyulah yang mewajibkan orang mengetahui Tuhan dan berterima kasih kepada-Nya.

Fungsi wahyu sangat banyak sekali, sekiranya wahyu 
tidak ada, maka manusia akan bebas berbuat apa saja yang dikehendakinya, dan sebagai akibatnya masyarakat akan berada dalam kekacauan.

\section{Karakteristik Kajian Fiqh}

Secara umum kaijan fiqh ditandai oleh bebeerapa karakteristik. Pertama karakteristik epistemik, yaitu, (1) sampai batas tertentu kurang memisahkan antar waktu dan sejarah, (2)univokalisasi makna, dan (3) nalar tranhistoris (abadi). Karakteristik lain adalah, (1) pemujsatan pada studi hukum islam sebagai law in book, tidak mencakup law in action, (2) percabangan materi yang rumit, tanpa memperhatikan referensi yang berkembang. ${ }^{27}$ (3) sifat polemik, dan apologetik, (4) inward looking, dan (5) pendekatan atomistik.

Posisi fikih sebagaimana telah dikemukakan terdahulu harus dikoreksi. Pertama, dengan menyadari mana yang mitos dan mana yang historis. Kedua, paradigma klasik yang optimistik seperti dikemukakan di atas yang mana diakui setiap linguistik pasti mempunyai makna khusus yang telah tertentu membawa makna univokalisasi makna. Ketiga, pandang tentang nalar abadi melahirkantradisi formal yang memperlakukan hukum (fiqh) sebagai bangunan pikiran dan

\footnotetext{
${ }^{27}$ Lihat kritik al-ghozali dalam Ihya' 'Ulum ad-Din (Baerut : Dar al Fikr,1995), 1:26, dimana ai mengatakan, “ Dan apabila engkau bertanya kepada Ahli fiqh tentang Li'an, zihar, pacuan dan pemanahan, makan ia menyajikan kepada anda berjilid-jilid percabangan fiqh yang rumityang sampai akhir zaman sekalipun tidak pernah dibutuhkan...”
} 
teks yang bersifat tranhistorisdan met-positif, berada di luar masyarakat dan tidak tersentuh oleh perubahan-perubahan sejarah. Hal ini diharapka mengenai paradigma pemaduan wahyu danrakyu dengan unufied approach to syari'ah and social inference seperti ditawarkan oleh Louay Safi atau pendekatan sui generis-kum empiris seperti di kemukan terdahulu. 28

Pendekatan klasik dalam kajian fiqh adalah atomistik, sebagai contoh adalah atomistik, sebagai contoh apabila kita membuka kitab-kitab fiqh klasik, misalnya bab muamalat, atau jinayat, kita akan dibawa langsung masuk kdalam uraian mengenai berbagai detail fiqh, misalnya dalam kajian tentang perjanjian (akad), kita lagsung dihadapkan kepada berbagai kasus tanpa didhului dengan kajian tentang asas umum yang menyemangati aneka perjanjian khusus itu. Bahkan ciri atomistik masih terbawa dalam Majallah al-Ahkam al'Adliyyah sebagai kodifikasi awwal tentang perjanjian Islam. Kritik yang diajukan terhadap KUH perjanjian Islam ini adlah tidak adanya asas umum yang menjadi sendi berbagai ketentuan detail hukum perjanjian di dalamnya.

Untuk studi fiqh sebagai hukum perlu dilakukan pendekatan asas-asas dan filosifi yang akhir-akhir ini mulai dilakukan dengan lahirnya apa yang kemudia yang dikenal an-nazariyyat al-fiqhiyyah. Untuk itu norma-norma fiqh dapat

\footnotetext{
${ }^{28}$ Anwar, Metodologi Hukum Islam,..., hal. 9.
} 
ditata dalam tiga jenjang, yaitu (1) nilai dasar (al-qiyam alasasiyyah), (2) asas-asas umum/dotrin-doktrin umum (al-usul al-kuliyyah) yang terdiri dari dua komponen (i) an-nazariyyah al-fiqhiyyah (asas-asas hukum Islam) dan (ii) al-qowid alfiqhiyyah (kaidah-kaidah hukum Islam), dan (3) peraturan hukum kongkret ( al-ahkam al-far'iyyah). 29

\section{Penutup}

Doktrin kemerdekaan berkehendak manusia seperti dicanangkan oleh kaum Mu'tazillah menjadi bagian dan konsep teologi mengenai "keadilan Tuhan" dan mengalahkan segi aslinya yaitu kemerdekaan dan tanggung jawab manusia. Di antara kaum ortodoks, kemerdekaan manusia ini berarti ketidak-merdekaan Tuhan. Mereka menuduh aliran Mu'tazilah sebagai humanisme yang ekstrim; yang mereka menegaskan bahwa Tuhan berada diluar konsep manusia tentang keadilan. Apa yang dipandang manusia sebagai keadilan Tuhan tidaklah berarti demikian bagi-Nya, tetapi apa yang diperbuat-Nya bagi manusia memang tampak adil dan rasional bagi manusia. Sesungguhnya, kaum Mu'tazilah membawa rasionalisme mereka sedemikian jauhnya dengan mensejajarkan kemampuan akal dengan wahyu dalam menemukan kebenaran agama adalah bahwa Allah telah melengkapi dan memodali manusia dengan penghargaan

\footnotetext{
${ }^{29}$ Ibid., 10.
} 
yang sangat tinggi yaitu akalnya untuk mengubah wajah dunia menjadi lebih baik serta dengan akal pula kita akan semakin mengetahui akan hakikat keberadaan dan kemaha kuasaan dan keadilan Allah SWT.

Keterlibatan akal dalam menemukan hukum, bukanlah suatu kekafiran, bahkan bukan pula sebagai bentuk persaingan dengan Allah, akan tetapi akal merupakan penjabaran manusia sebagai makhluk yang dilebihkan dari makhluk lain, sehingga konsekwensi tersebut berdampak kepada paradigma model-model metodoıgi dalam pengistinbatan Hukum Islam di kalangan para intelektual muslim. Kalau kita tidak mengoptimalisasikan potensi akal dalam kehidupan ini, maka manusia akan berwatak pesimis, statis, bahkan tidak dapat mengelola alam yang sudah dianugerahi Allah dengan sejuta sumber kekayaan yang gemilang yang terkandung di dalamnya, seperti batu bara, minyak bumi, emas, perak, air, dan lain-lain. 


\section{Daftar Pustaka}

Ahmad, Noer, dkk, Epistimologi Syara '-Mencari Format Baru Fiqh Indonesia (Yogyakarta, Pustaka Pelajar, 2000).

Anwar, Syamsul, Metodologi Hukum Islam (Yogyakarta, 2006).

------, Pengantar makalah “ Paradigma Fiqh Kontemporer mencari förmat baru telaah Hukum Islam “..

Coulson, J, Noel, Konflik Dalam Yurisprudensi Islam, Pengantar Akh. Minhaji,

(Yogyakarta, Navila)

Djamil, Fathurrahman, Metode Ijtihad Tarjih Muhammadiyah (Jakarta: Logos Publishing Press, 1995).

------, Filsafat Hukum Islam (Jakarta: Logos Wacana Ilmu, 1999).

Ghazali, Al, Mustafa Min ilm Ushul (Beirut/Libanon: AlRisalah, 1994).

Goldziher, Ignaz, Introductions To Islamic Theology And Law, terj. Indonesia. Pengantar Teologi dan Hukum Islam (Jakarta: ENIS, 1991).

Guba, dan, Lincoln, Naturalistic Inquiry (Bavery Hill, California: Sage Publications, inc, 1985).

Hallaq, B, WeaI, Authority Continuity And Change In Islamic Law (New York: Cambridge University Press, 2001). Iqbal, M, The Reconstructions Of Religious Thought in Islam (India: Kitab Bhava V, 1981). 
Machasin, Menyelami Kebebasan Manusia-Telaah Kritis Terhadap Konsepsi Al-qur 'an (Yogyakarta: INIS, 1996).

Mu’alim, Amir, \& Yusdian, Konfigurasi Pemikiran, Hukum Islam (Yogyakarta, UII Press, 2004).

Nasution, Harun, Teologi Islam- Aliran-aliran Sejarah Analisis Perbandingan, (Jakarta: Universitas Indonesia Press, 1986).

Syatibi, As, Al-Muwafaqat Fi Ushul Al-Ahkam, juz 2 (Beirut: Dar-Fikr, 1342).

Sulayman, Abdul, Towards An islamic Theory Of international Relarions: new directions for methogology and thougt (Hernden, VA: International Of Islamic Thought, 1994).

Weiss, G.Bernard, The Search For God'c Law Islamic Jurisprudence In The Writing of Saif Al-Amidi (Salt Lake City: University Of Utah Press, 1992). 